\title{
Oksidacijski i antimikrobni učinci alicina
}

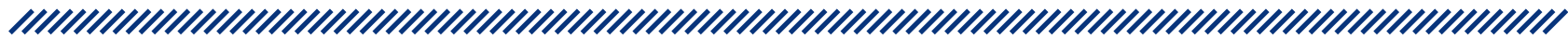

1 Rafaela Bartulović

2 Lana Feher Turković

2 Ana Mojsović Ćuić

1

2 Zdravstveno veleučilište, Mlinarska cesta 38, Zagreb

\section{SAŽETAK}

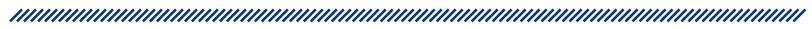

Alicin (dialil-tiosulfinat ili dialil-disulfid-oksid, $\mathrm{C}_{6} \mathrm{H}_{10} \mathrm{OS}_{2}$ ) je obrambeni organosumporni spoj koji pronalazimo $u$ bijelome luku (Allium sativum L.) te u drugim vrstama roda Allium poput crvenoga luka (Allium cepa L.). Alicin se proizvodi pri oštećenju tkiva češnjaka iz aminokiseline aliina (S-alil-cistein-sulfoksid) u reakciji koja je katalizirana enzimom aliinazom. Smatra se glavnom komponentom bijeloga luka koji se proučava i upotrebljava u medicinske svrhe još od davnina. Karakterističan i lako prepoznatljiv miris bijeloga luka potječe upravo od alicina. Alicin je molekula sa širokim spektrom bioloških aktivnosti. Kao tiosulfinat, pripada reaktivnim sumpornim spojevima (RSS) te ulazi u redoks-reakciju s tiolnim skupinama u glutationu i proteinima, što se smatra esencijalnim za njegovu biološku aktivnost. Pokazao je nedvojbene korisne učinke na ljudsko zdravlje, među kojima su najvažniji antimikrobni i antiparazitni učinci. Posebna pozornost $u$ istraživanjima posvećuje se i njegovim antikancerogenim, antidijabetičkim, imunomodulatornim, antioksidacijskim i kardioprotektivnim učincima. Alicin pokazuje potencijal za prevenciju i

tretiranje nekoliko bolesti, uključujući diabetes melitus, kardiovaskularne bolesti i rak. Vjeruje se da takav biološki učinak ima upravo zbog svojih antioksidacijskih i imunomodulatornih svojstava. Jasno je da alicin ima široku i zanimljivu primjenu u medicini, odakle i detaljna rasprava o njegovu ogromnom potencijalu u ovom pregledu. Buduće primjene trebale bi se usmjeriti na farmaceutsku formulaciju alicina, njegovu isporuku te kompatibilnost s hranom i lijekovima zbog njegove biosinteze, nestabilnosti, hlapljivosti i reaktivnosti.

Ključne riječi: alicin, antioksidans, antimikrobno djelovanje

Klasifikacija: stručni rad

Datum primitka: 15.10.2021.

Datum prihvaćanja: 15.12.2021.

https://doi.org/10.24141/1/8/1/12

Adresa za dopisivanje:

Rafaela Bartulović, Hrvatska

e-pošta: rafaela.bartulovic1@gmail.com

Telefon: +385958442163 


\section{UVOD}

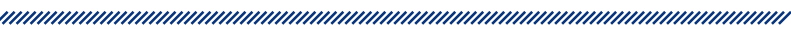

Biljke se upotrebljavaju od samih početaka ljudske civilizacije, a neke od njih mogu pružiti izvanredne učinke za liječenje bolesti kao što su psihijatrijske bolesti (anksioznost i depresija) i kardiovaskularni poremećaji (mogu djelovati kao vazorelaksanti i vršiti pozitivne učinke na srčanu hipertrofiju, angiogenezu, agregaciju trombocita, hiperlipidemiju i hiperglikemiju) ili imaju izraženu antimikrobnu aktivnost. ${ }^{1}$ Općenito, iako ne sasvim točno, shvaćanje prirodnih proizvoda kao blagih i uglavnom bezopasnih u usporedbi s kemijski sintetiziranim srodnim spojevima jedan je od razloga njihove sve veće uporabe kod potrošača, kako u medicini tako i u drugim granama (npr. poljoprivredi).2 lako se farmaceutska industrija posljednjih desetljeća uglavnom fokusirala upravo na kemijski sintetizirane spojeve, tj. lijekove, upotreba prirodnih proizvoda u ljekovite i antimikrobne svrhe drevna je praksa. ${ }^{2}$

Drevni tekstovi kao što je egipatski Codex Ebers (Ebers Papyrus) i grčki Čarobni papirus precizno spominju upotrebu ekstrakata češnjaka u ljekovite svrhe. Vergilije, rimski pjesnik iz prvog stoljeća prije Krista, istaknuo je njihovu upotrebu u liječenju zmijskih ugriza. Poznati grčki liječnik Hipokrat također je opisao učinkovitost ekstrakata češnjaka u liječenju upale pluća i zacjeljivanju rana u svojem djelu Corpus Hippocratum. ${ }^{2}$ Putovanje češnjaka kroz vrijeme i povijest bogato je i živopisno - u starijim vremenima upotrebljavao se u najrazličitije svrhe, od sredstva za odbijanje vampira do protuotrova za ugrize pasa. ${ }^{2}$

lako je crveni luk najčešće korišteni pripadnik roda Allium i jedna od najkonzumiranijih namirnica na svijetu, upravo je njegov oštriji srodnik češnjak, nadaleko poznat po prepoznatljivom mirisu, pridobio veću pozornost znanstvenika. ${ }^{2}$ lako je kulinarska, terapeutska, pa čak i spiritualna vrijednost češnjaka prepoznata i priznata stoljećima, o njemu se nije mnogo znalo prije nego što su Cavallito i Bailey 1944. izvijestili o prisutnosti alicina u češnjaku i opisali njegova svojstva. Tek se tada stekao jasniji uvid u kemijsku prirodu češnjaka, čime su započela desetljeća opsežnih istraživanja alicina. Povrće iz roda Allium sadrži mnogo različitih bioaktivnih spojeva, uključujući flavonoide, oligosaharide, arginin i selen; međutim, većinu zdravstvenih prednosti vrsta Allium, na koje je i fokusirana glavnina istraživanja, predstavljaju komponente koje sadrže sumpor (tiosulfi- nati (na primjer, alicin), azen (npr. E-ajoeni, Z-ajoeni), vinilditini (npr. vinil-l, 3-ditin, vinil-l, 2-ditin) i sulfidi (npr. dialil-disulfid (DADS) i dialil-trisulfid (DATS)) ${ }^{3}$. Nekoliko provedenih istraživanja ukazuje na potencijal alicina kao antimikrobnog, kardioprotektivnog i antifibrotičkog agensa te na to da posjeduje svojstva antioksidansa, kao i antikancerogena svojstva.

\section{OSNOVNO O ALICINU}

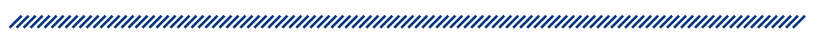

Alicin je vrlo hlapljiva svjetložuta uljasta tekućina niske topljivosti u vodi koja ima prepoznatljiv opor miris češnjaka. Češanj češnjaka sadržava približno 4 do $5 \mathrm{mg}$ alicina, a njegovu je prisutnost lako otkriti zbog jedinstvenog mirisa. ${ }^{4}$

Alicin se ne nalazi u netaknutom režnju češnjaka, već nastaje enzimskom reakcijom iz prekursora aliina uz piruvat i amonijak kada se ošteti tkivo češnjaka. Aliin i aliinaza zatvoreni su u različite odjeljke unutar češnja bijelog luka. Pri oštećenju biljke aliin i aliinaza dolaze u kontakt kako bi proizveli alicin, spoj koji brani biljku od bakterija, gljiva i životinjskih grabežljivaca.

Alicin ima vrlo kratak poluživot, nestabilan je te se odmah metabolizira u mnoge druge sekundarne spojeve, ovisno o temperaturi i pH-vrijednosti. Raspada se u organske dialilne polisulfide, dialil-sulfid (DAS), dialil-disulfid (DADS) i dialil-trisulfid (DATS) i ajoene. ${ }^{3}$ Biosinteza alicina u velikoj količini ili njegov dug poluživot mogli bi biti toksični za biljna tkiva i enzime, stoga njegov vrlo ograničeni nastanak i kratkotrajna reaktivnost, ograničena na područje na kojem se događa mikrobni napad, umanjuje potencijalno samooštećenje biljke. Alicin pod utjecajem temperature prelazi u stabilnije spojeve (ajoene i vinilditine). Pokazalo se da prisutnost octa u pripravcima češnjaka povećava rok trajanja alicina zbog niže pH-vrijednosti. Utvrđeno je da je pri pH-vrijednosti 5 do 6 vrijeme poluživota alicina 10 do 17 dana. ${ }^{4}$

Alicinu se može pripisati širok spektar bioloških aktivnosti. Pri njegovoj primjeni alicin brzo prolazi kroz stanične membrane zahvaljujući svojoj hidrofobnoj prirodi te nestaje iz cirkulacije nakon svega nekoliko minuta. Također, alicin kao reaktivni sumporni spoj s oksidacijskim svojstvima brzo reagira sa slobodnim tiolnim skupinama glutationa i cisteina u proteinima te ih oksidira. 
Oksidacija proteinskih tiola može dovesti do promjene strukture proteina stvaranjem disulfidnih veza, što može rezultirati promjenama u funkcionalnosti (bilo gubitkom bilo dobitkom funkcije). Time se može objasniti i širok spektar njegova djelovanja. ${ }^{2}$

\section{BIOSINTEZA ALICINA}

Češnjak (Allium sativum L.) sadrži mnoge tvari, među kojima i sumporne spojeve (kao što su alicin, aliin, ajoeni, alil-propil-disulfid, dialil-trisulfid, S-alil-cistein, vinilditini i S-alil-merkaptocistein) koje proizvode i mnoge druge vrste roda Allium. Alicin $\left(\mathrm{C}_{6} \mathrm{H}_{10} \mathrm{OS}_{2}\right)$ je tiosulfinat, a njegovu strukturu utvrdili su Stoll i Seebeck $1948 .^{5}$

U prirodi, nakon oštećenja biljnog tkiva, alicin se proizvodi enzimskom reakcijom. Prekursor alicina jest neproteinogena aminokiselina aliin (S-alil-L-cistein sulfoksid) koja se pod djelovanjem enzima aliinaze pretvara u alicin. $U$ neoštećenim režnjevima češnjaka aliin i aliinaza razdvojeni su u citoplazmi te vakuoli. ${ }^{6}$ Nakon mehaničkog oštećenja biljnog tkiva ili infekcije mikroorganizmima, aliin i aliinaza se spoje. ${ }^{7}$ Aliin se pod djelovanjem aliinaze pretvara u alil-sulfensku kiselinu (2-propenesulfenska kiselina) i dehidroalanin. Alil-sulfenska kiselina nestabilan je i visokoreaktivan spoj na sobnoj temperaturi. Dvije molekule alil-sulfenske kiseline spontano se kondenziraju tvoreći alicin uz posljedično uklanjanje vode. ${ }^{2}$ Zanimljivo je da crveni luk (Allium cepa L.) ne sintetizira aliin, već njegov izomer izoaliin. ${ }^{8}$ Biosintetski put do aliina još uvijek nije jasan. Na temelju eksperimenata s radioaktivnim obilježavanjem Ganroth je predložio dva biosintetska puta. ${ }^{2}{ }^{9}$ Granroth je uspio dokazati da dvostruka veza u izoaliinu potječe od metakrilne kiseline, ali to nije bio slučaj za aliin pa izvor dvostruke veze u aliinu ostaje nepoznat. Nadalje, Granroth je pokazao da crveni luk isto tako može proizvoditi aliin kada se opskrbi alil-merkaptanom ili ekstraktom kuhanog češnjaka. Pokazalo se da ne samo cistein nego i serin može biti izvor aminokiselinskog dijela aliina. To je postignuto opskrbljivanjem crvenoga luka 14C-obilježenim serinom i raznim tiolima. U svim je slučajevima Granroth izvijestio o nastanku 14C-obilježenog S-alkilL-cistein sulfoksida, s alkilnom skupinom koja odgovara dodanom tiolu. ${ }^{9}$

U laboratoriju se alicin može sintetizirati oksidacijom dialil-disulfida (DADS) s vodikovim peroksidom, magnezijevim monoperoksiftalatom ili kloroperbenzoevom kiselinom. Uz kemijsku sintezu alicina objavljeni su protokoli za njegovu enzimatsku proizvodnju in vitro. Supstrat aliin može se ekstrahirati iz češnja češnjaka ili sintetizirati iz cisteina alkilacijom alil-bromidom, nakon čega slijedi oksidacija vodikovim peroksidom. Zbog visoke reaktivnosti alicina i niske toplinske stabilnosti teško je dobiti i pohraniti čisti alicin bez onečišćenja srodnim spojevima poput ajoena, vinildihtina ili polisulfana. Ipak, u razrijeđenim vodenim otopinama na $-70{ }^{\circ} \mathrm{C}$ pripravci ostaju stabilni tijekom godina (nema gubitaka ni nakon dvije godine). ${ }^{2}$

\section{OKSIDACIJSKO DJELOVANJE ALICINA}

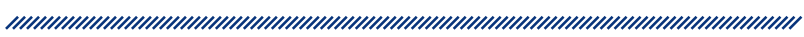

Unutarstanični odjeljci moraju imati regulirane, ali individualno različite uvjete kako bi se održali biokemijski stanični procesi za metabolizam. Stoga ionska koncentracija, pH-vrijednost i odgovarajući redoks-potencijal moraju biti pažljivo održavani. ${ }^{2}$ Redoks-reakcije uobičajene su u stanicama, a u njima dolazi do izmjene elektrona između dva redoks-sustava. U biološkim se sustavima mnoge reakcije događaju istodobno. Stanice općenito imaju negativni citosolni redoks-potencijal, što znači da je citosol u reduciranom ili reducirajućem stanju. Stanični redoks-potencijal kontrolira se u velikoj mjeri GSH/GSSG redoks-parom (engl. glutation-pool) s $N A D(P) H / N A D(P)+$ parom i tioredoksinima. ${ }^{2}$ Glutation je tripeptid koji se sastoji od glutaminske kiseline, cisteina i glicina. Pronalazimo ga u visokoj koncentraciji u većini stanica ( $5 \mathrm{mmol} / \mathrm{L}$ ). To znači da ima otprilike istu koncentraciju u stanicama kao glukoza, kalij i kolesterol. Važnost glutationa dodatno naglašava visoka razina metaboličke aktivnosti potrebne za njegovu proizvodnju. ${ }^{10}$ Glutation postoji u stanicama u dvama stanjima: reduciranom (GSH) i oksidiranom (GSSG). Odnos GSH-a prema GSSG-u određuje redoks-status stanica. Zdrave stanice u mirovanju imaju omjer GSH/GSSG >100, dok omjer pada na 1 do 10 u stanicama izloženima oksidacijskom stresu. Glutation ima važnu ulogu u antioksidativnoj obrani, metabolizmu hranjivih tvari i regulaciji staničnih događaja (uključujući ekspresiju gena, sintezu DNA-a i proteina, staničnu proliferaciju i apoptozu, 
transdukciju signala, proizvodnju citokina i imunološki odgovor te glutation-proteinaciju). Nedostatak glutationa pridonosi oksidacijskom stresu koji ima ključnu ulogu u starenju i patogenezi mnogih bolesti. Alicin lako prolazi kroz membranu stanica te reagira sa slobodnim tiolnim skupinama i oksidira dostupne cisteine $u$ glutationu i proteinima. Alicin oksidira glutation (GSH) u S-alil-merkaptoglutation (GSSA) smanjujući stanične zalihe GSH, što dovodi do oksidacijskog stresa u stanici. Nadalje, alicin oksidira dostupne cisteine u proteinima dajući S-alil-merkapto-adukte. Time može doći do inhibicije esencijalnih enzima (npr. promjenom trodimenzionalne strukture bjelančevina, sprečavanjem vezanja kofaktora metala...), što može rezultirati gubitkom ili dobitkom funkcije proteina. Pretpostavlja se da bi inaktivacija esencijalnih enzima mogla objasniti toksičnost alicina te da su upravo ova svojstva alicina odgovorna i za njegovo antimikrobno djelovanje. Naime, tiolne skupine prisutne su u svim živim stanicama te se alicin može smatrati biocidom koji, ovisno o dozi, ima sposobnost ubiti eukariotske stanice. Alicin može inducirati apoptozu u različitim tipovima stanica. ${ }^{11}$ Unatoč tome što je alicin s kemijskog gledišta oksidacijsko sredstvo, alicin i proizvodi od češnjaka u prehrambenoj se industriji smatraju antioksidansima. ${ }^{11}$

\section{ANTIMIKROBNI UČINCI ALICINA}

Izvješća o ciljanoj upotrebi češnjaka kao antimikrobnog agensa sežu do Louisa Pasteura, a u Prvom svjetskom ratu ekstrakti češnjaka primjenjivali su se kao antibakterijska i antiseptička sredstva. ${ }^{2}$ Tijekom godina objavljena su i brojna znanstvena istraživanja povezana s antimikrobnim potencijalom češnjaka. Utvrđeno je da alicin u svojem čistom obliku pokazuje antibakterijsko djelovanje protiv širokog spektra gram-negativnih i gram-pozitivnih bakterija, uključujući enterotoksične sojeve E. coli otporne na više lijekova. Alicin posjeduje i protugljivično djelovanje (istraživanja provedena na Candida albicans), antiparazitsko djelovanje protiv glavnih ljudskih crijevnih parazita (Entamoeba histolytica i Giardia lamblia) te antivirusno djelovanje.12 Antimikrobni učinak alicina ponajprije je posljedica njegove kemijske reakcije s tiolnim skupinama različitih enzima.

Tijekom 1940-ih provedeno je ispitivanje više organo- sumpornih spojeva iz češnjaka na antimikrobno djelovanje. Ni dialil-disulfidi (DADS) koji nastaju razgradnjom alicina ni dialil-polisulfani ne pokazuju znatno antimikrobno djelovanje ako se ne primjenjuju u vrlo visokim koncentracijama. Koch i Lawson odredili su minimalnu koncentraciju ovih spojeva koja je potrebna za inhibiranje rasta bakterija Escherichia coli i Staphylococcus aureus. ${ }^{2}$ Prema njihovim rezultatima, potrebno je približno 35 puta više dialil-disulfida $(6,15 \mathrm{mM})$ kako bi se inhibirao rast ovih dviju bakterija u usporedbi s alicinom $(0,17 \mathrm{mM})$. Činjenica da DADS, kao jedan od izravnih produkata razgradnje alicina, ima znatno niže antimikrobno djelovanje ukazuje na to da tiosulfinatna skupina ima važnu ulogu u antimikrobnoj aktivnosti jer biva izgubljena tijekom redukcije alicina u DADS.

\section{ANTIBAKTERIJSKI UČINCI}

Različiti pripravci češnjaka pokazali su širok spektar antibakterijskog djelovanja protiv gram-negativnih i grampozitivnih bakterija kao što su Escherichia, Salmonella, Staphylococcus, Streptococcus, Klebsiella, Proteus, Bacillus i Clostridium. Bakterije kao što je Mycobacterium tuberculosis također su osjetljive na pripravke češnjaka. ${ }^{12}$ Ekstrakti češnjaka učinkoviti su protiv Helicobacter pylori. ${ }^{1}$

Small i suradnici kemijski su sintetizirali razne tiosulfinate, uključujući i sam alicin, koji su se razlikovali u alkilnim skupinama, tj. u duljini lanaca i grananju. Testirali su ih na dvadeset različitih bakterijskih izolata utvrđujući minimalnu koncentraciju potrebnu za bakteriostatski učinak u tekućoj kulturi. Nakon toga iznijeli su dva temeljna zapažanja: prvo, grananje alkilnih skupina rezultiralo je smanjenom antibakterijskom aktivnošću. Na primjer, za bakteriostatski učinak bilo je potrebno dva puta više derivata $s$ razgranatom alkilnom skupinom od derivata bez nje. Od svih ispitivanih derivata onaj s najrazgranatijom alkilnom skupinom, tert-butiletil tiosulfinat, pokazao je najslabiju antibakterijsku aktivnost od svih tiosulfinata (koncentracija od 60 do $>1200 \mu \mathrm{M})$. Pokazalo se da je najučinkovitiji tiosulfinat n-pentil-tiolsulfinat $(0,7$ do $130 \mu \mathrm{M})$, koji je bio nešto učinkovitiji od alicina (50 do $150 \mu \mathrm{M}$ ). Isto tako, bio je mnogo stabilniji od alicina jer ne posjeduje dvostruke veze. Kao drugo, opazili su da je bakteriostatski učinak tiosulfinata na gram-pozitivne bakterije postao jači povećanjem duljine ugljikova lanca, ali istodobno slabiji na gram-negativne bakterije. ${ }^{2}$

Ovisno o organizmu i primijenjenom antibiotiku, učinkovitost konvencionalnih antibiotika poput $\beta$-laktama 
(penicilin i derivati poput ampicilina) ili glikozidnih antibiotika poput kanamicina usporediva je $s$ alicinom. ${ }^{2}$ Različiti sojevi bakterija koji su razvili otpornost na antibiotike $u$ istraživanjima su pokazali osjetljivost na alicin. Primjer je vrsta zlatnog stafilokoka MRSA (meticilin-rezistentni Staphylococcus aureus) koji pokazuje otpornost na penicilinske i mnoge druge antibiotike. Pokazalo se da alicin učinkovito inhibira ovu bakteriju koja je ujedno glavni krivac za mnoge bolničke infekcije. Tu su i drugi multirezistentni enterotoksični sojevi bakterija Escherichia Coli, Enterococcus, Shigella dysenteriae, Shigella flexneri i Shigella sonnei osjetljivi na alicin. ${ }^{12}$ Alicin je pokazao i in vivo antibakterijsko djelovanje protiv S. flexneri Y kada je bio testiran na zecu oboljelom od šigeloze. ${ }^{12}$

S druge strane, za sojeve bakterija kao što su Pseudomonas aeruginosa, Streptococcus $\beta$-hemolyticus i Enterococcus faecium utvrđeno je da su rezistentne na djelovanje alicina. Razlozi su rezistencije nejasni. Pretpostavlja se da hidrofilni kapsularni ili mukoidni slojevi sprječavaju prodiranje alicina u bakteriju, ali to bi trebalo detaljnije proučiti. ${ }^{12}$ Sinergijski učinak alicina protiv bakterije M. tuberculosis utvrđen je kod antibiotika poput streptomicina ili kloramfenikola. ${ }^{12}$ Zanimljiv je aspekt antibakterijskog djelovanja alicina nesposobnost većine bakterija da na njega razviju rezistentnost, jer se način djelovanja alicina potpuno razlikuje od načina na koji djeluju druge antibiotske tvari. Ustanovljeno je da je razvoj rezistencije na $\beta$-laktamske antibiotike tisuću puta lakši od razvoja rezistencije na alicin. ${ }^{12}$

\section{ANTIFUNGALNI UČINCI}

Osim antibakterijskih svojstava, alicin pokazuje i toksične učinke na stanice gljiva i sposoban je inhibirati klijanje spora i rast hifa in vivo i in vitro. ${ }^{2}$ Vrste Botrytis cinerea, Plectospherella cucumerina, Alternaria brassicicola i Magnaporthe grisea koje su biljni patogeni, in vitro su snažno inhibirane alicinom u testu difuzije na agaru zasađenom sporama. ${ }^{2} \mathrm{U}$ daljnjim je istraživanjima ustanovljeno da je učinkovita i dezinfekcija sjemenki sokom češnjaka. Pokazano je da su sjemenke mrkve zaražene gljivama Alternaria spp. te dezinficirane sokom svježeg češnjaka dezinficirane u stupnju usporedivom s komercijalnim proizvodom za dezinfekciju sjemenki. ${ }^{2} U$ drugom su istraživanju klijanje i razvoj patogenom zaraženih sjemenki pšenice bili znatno uspješniji zahvaljujući prethodnom tretiranju sokom češnjaka. ${ }^{2}$ Zbog svega toga alicin bi mogao imati potencijal kako u ekološkoj poljoprivredi, tako i u uvjetima niske tehnologije (npr. u zemljama u razvoju). Budući da se alicin lako dobiva iz svježe oštećenog tkiva češnjaka, poljoprivrednicima je vrlo dostupan te bi mogli uzgajati češnjak i upotrebljavati ga kao vlastiti pesticid.

Osim uporabe u poljoprivredi, u fokusu su interesa i gljivične infekcije ljudi i životinja. Alicin inhibira stvaranje mikotoksina poput aflatoksina Aspergillus parasiticus. ${ }^{12}$ Alicin se lako može i lokalno primijeniti na gljivične infekcije kože, stoga se pokušalo primijeniti alicin u terapiji infekcije Candidom. Utvrđeno je da čisti alicin ima visoko antikandidalno djelovanje $s$ minimalnom inhibitornom koncentracijom od $7 \mu \mathrm{g} / \mathrm{mL}{ }^{12}$ Zanimljivo je da je djelotvornost alicina bila usporediva s često korištenim antimikotikom flukonazolom. ${ }^{2} \mathrm{U}$ svojim istraživanjima Yamada i Azuma ${ }^{12,13}$ utvrdili su da je čisti alicin učinkovit in vitro protiv sljedećih vrsta: Candida, Cryptococcus, Trichophyton, Epidermophyton i Microsporum u niskim koncentracijama (minimalne inhibitorne koncentracije bile su između 1,57 i 6,25 $\mathrm{gg} / \mathrm{mL}$ ). Mirelman i suradnici utvrdili su znatnu osjetljivost različitih klinički važnih gljivica na čisti pripravak alicina. ${ }^{12}$ Razna istraživanja o učinku alicina na pekarski kvasac isto tako pokazuju da alicin djeluje sinergijski s drugim poznatim fungitoksičnim tvarima poput bakra. ${ }^{2}$

\section{ANTIPARAZITNI UČINCI}

Istraživanja provedena na ljudskom crijevnom parazitu iz koljena praživotinja (protozoa) Entamoeba histolytica ukazuju na njegovu veliku osjetljivost na alicin. Samo $30 \mu \mathrm{g} / \mathrm{mL}$ alicina u potpunosti inhibira rast kultura ameba. ${ }^{14}$ Alicin pri nižim koncentracijama inhibira virulenciju trofozoita Entamoeba histolytica, što je potvrđeno njihovom nesposobnošću uništavanja monoslojeva stanica sisavaca uzgojenih in vitro. ${ }^{12}$ Alicin u koncentraciji $30 \mu \mathrm{g} / \mathrm{mL}$ vrlo učinkovito inhibira rast drugih parazita protozoa kao što su Giardia lamblia, Leishmania major, Leptomonas colosoma i Crithidia fasciculata. ${ }^{12}$

Izvjesna toksičnost alicina prema uzgojenim stanicama sisavaca primijećena je tek u koncentracijama iznad $100 \mu \mathrm{M}$. Međutim, zanimljivo je da pri ovim visokim koncentracijama nije opaženo oštećenje stanica sisavaca ako se inkubacija izvršavala u prisutnosti trofozoita ameba. To pokazuje da je afinitet molekula alicina veći prema stanicama parazita. Razlog veće osjetljivosti stanica parazita na alicin jest što većina stanica parazita i općenito stanica mikroorganizama nema ili ima vrlo male količine glutationa (ili ekvivalentnih molekula poput tripanotiona) te zbog toga ne mogu reaktivirati esencijalne-SH enzime koji bivaju tiolirani alicinom. ${ }^{12}$ 


\section{ANTIVIRALNI UČINCI}

Ekstrakti svježeg češnjaka pokazuju in vitro i in vivo antivirusno djelovanje. Među viruse koji su osjetljivi na ekstrakte češnjaka ubrajaju se humani citomegalovirus, virus gripe tip $B$, virus herpes simplex tip 1 , virus herpes simplex tip 2, virus parainfluence tip 3 , virus vakcinije, virus vezikularnog stomatitisa i humani rinovirus tip 2.12 Kondenzacijski produkt alicina, ajoen, općenito pokazuje bolju antiviralnu aktivnost od samog alicina. Ajoen blokira procese ovisne o integrinu u stanicama zaraženima virusom humane imunodeficijencije.12 Zanimljivo je da postoje neki virusi poput virusa biljke češnjaka X koji su otporni na antivirusno djelovanje ekstrakata češnjaka. ${ }^{15}$

\section{ZAKLJUČAK}

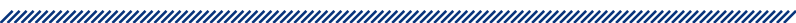

Alicin je fiziološki aktivna molekula s mnogim potencijalnim zdravstvenim blagodatima za ljudsko zdravlje. Sposobnost interakcije alicina $s$ tiolnim skupinama izravno je povezana s njegovim antimikrobnim potencijalom te pokazuje antibakterijsko, antifungalno, antiviralno i antiparazitno djelovanje.

Potrebna su daljnja istraživanja kako bi se produbila znanja i o drugim ključnim aspektima, poput parametara kvalitete i sigurnosti, čistoće, podrijetla, stabilnosti, bioraspoloživosti, bioefikasnosti, nuspojava i toksičnosti.

Nestabilnost alicina jedan je od aspekata koji je najviše ograničio napredak kliničkih istraživanja i primjenu. Budući napori trebali bi se usmjeriti na farmaceutsku formulaciju alicina, njegovu isporuku i kompatibilnost s hranom i drugim lijekovima zbog njegove nestabilnosti, reaktivnosti i hlapljivosti.

\section{LITERATURA}

"2

1. Sharifi-Rad J, Cirone Silva NC, Jantwal A, Bhatt ID, Sharopov F, Cho WC, Taheri Y, Martins N.: Therapeutic Potential of Allicin-Rich Garlic Preparations: Emphasis on Clinical Evidence toward Upcoming Drugs Formulation. Applied Sciences 2019.

2. Borlinghaus J, Albrecht F, Gruhlke M, Nwachukwu I, Slusarenko A. Allicin: Chemistry and Biological Properties. Molecules 2014, 19 (8), 12591 12618. Dostupno na: https://doi.org/10.3390/molecules190812591

3. Polunić A. Citotoksično djelovanje polisulfida iz porodice lukova (Allium spp.) na različite linije humanih karcinoma mjereno MTT metodom [diplomski rad]. Split: medicinski fakultet Sveučilišta u Splitu 2018.

4. Salehi B, Zucca P, Orhan IE, Azzini E, Adetunji CO, Mohammed SA, Ahmad Z. Allicin and health: A comprehensive review. Trends in Food Science \& Technology, 2019; 86: 502-516.

5. Stoll A, Seebeck E. Über Alliin, die genuine Muttersubstanz des Knoblauchöls. Helv. Chim. Acta. 1948;31:189 210. doi: 10.1002/hlca.19480310140.

6. Reiter J, Hübbers AM, Albrecht F, Leichert LIO, Slusarenko AJ. Allicin, a natural antimicrobial defence substance from garlic, inhibits DNA gyrase activity in bacteria, International Journal of Medical Microbiology, 2020; 310 (1), 151359, ISSN 1438-4221, Dostupno na: https://doi. org/10.1016/j.ijmm.2019.151359

7. Müller A, Eller J, Albrecht F, et al. Allicin Induces Thiol Stress in Bacteria through S-Allylmercapto Modification of Protein Cysteines. J Biol Chem. 2016; 291 (22): 11477-11490. doi: 10.1074/jbc.M115.702308. Dostupno na: https://www.ncbi.nlm.nih.gov/pmc/articles/ PMC4882420/

8. Virtanen AI, Matikkala EJ. The Isolation of S-methylcysteinesulphoxide and S-n-propenylcysteinesulphoxide from onion (Allium cepa) and the antibiotic activity of crushed onion. Acta Chem. Scand. 1959; 13: 1898-1900. doi: 10.3891/acta.chem.scand.13-1898.

9. Granroth B. Biosynthesis and decomposition of cysteine derivatives in onion and other Allium species. Ann. Acad. Sci. Fenn. Chem. 1970; 154: 4-71.

10. Pizzorno J. Glutathione!. Integr Med (Encinitas). 2014; 13 (1): 8-12. Dostupno na: https://www.ncbi.nlm.nih.gov/ pmc/articles/PMC4684116/

11. Gruhlke MC, Nicco C, Batteux F, Slusarenko AJ. The Effects of Allicin, a Reactive Sulfur Species from Garlic, on a Selection of Mammalian Cell Lines. Antioxidants (Basel). 2016 Dec 26; 6 (1): 1. doi: 10.3390/antiox6010001. PMID: 28035949; PMCID: PMC5384165.

12. Ankri S, Mirelman D. Antimicrobial properties of allicin from garlic. Microbes Infect. 1999 Feb; 1 (2): 125-129. doi: 10.1016/s1286-4579(99)80003-3. PMID: 10594976. Do- 
stupno na: https://pubmed.ncbi.nlm.nih.gov/10594976/

13. Yamada Y, Azuma K. Evaluation of the in vitro antifungal activity of allicin, Antimicrob. Agents Chemother., 1997; 11: 743-749.

14. Mirelman D, Monheit D, Varon S. Inhibition of growth of Entamoeba histolytica by Allicin, the active principle of garlic extract (Allium sativum) J. Infect. Dis., 1987; 156: 243-244.

15. Song SI, Song JT, Chang MU, Lee JS, Choi YD. Identification of one of the major viruses infecting garlic plants, garlic virus X, Mol. Cells, 1997; 7: 705-709. 


\section{OXIDATIVE AND ANTIMICROBIAL EFFECTS OF ALICINE}

1 Rafaela Bartulović

2 Lana Feher Turković

2 Ana Mojsović Ćuić

2 University of Applied Health Sciences, Mlinarska street 38, Zagreb, Croatia and cardioprotective effects. Allicin shows potential for the prevention and treatment of several diseases, including diabetes mellitus, cardiovascular disease and cancer. It is believed that it has such a biological effect precisely because of its antioxidant and immunomodulatory properties. It is clear that allicin has a wide and interesting application in medicine, hence the detailed discussion of its enormous potential in this review. Future applications should focus on the pharmaceutical formulation of allicin, its delivery, and compatibility with food and drugs due to its biosynthesis, instability, volatility, and reactivity.

\section{Abstract}

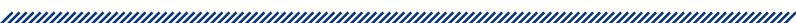

Allicin (diallylthiosulfinate or diallyl disulfide oxide, $\mathrm{C}_{6} \mathrm{H}_{10} \mathrm{OS}_{2}$ ) is a defense organosulfur compound found in garlic (Allium sativum L.) and in other Allium species such as red onion (Allium cepa L.). Allicin is produced by damaging garlic tissue from the amino acid alliin (Sallyl-cysteine sulfoxide) in a reaction catalyzed by the enzyme alinase. It is considered a major component of garlic that has been studied and used for medicinal purposes since ancient times. The characteristic and easily recognizable smell of garlic comes from allicin. Allicin is a molecule with a wide range of biological activities. As thiosulfinate, it belongs to reactive sulfur compounds (RSS) and enters into a redox reaction with thiol groups in glutathione and proteins, which is considered essential for its biological activity. It has shown unquestionable beneficial effects on human health, among which the most significant are antimicrobial and antiparasitic effects. Special attention in research is paid to its anticancer, antidiabetic, immunomodulatory, antioxidant
Keywords: allicin, antioxidant, antimicrobial action 